KS. ARKADIUSZ DOMASZK SDB

Wydział Prawa Kanonicznego

Uniwersytetu Kardynała Stefana Wyszyńskiego w Warszawie

ORCID: 0000-0002-7118-3102

\title{
TRANSPARENTNOŚĆ, PROGRAMOWALNOŚĆ I SPRAWOZDAWCZOŚĆ EKONOMICZNA INSTYTUTÓW ZAKONNYCH ${ }^{1}$
}

Treść: Wstęp. - 1. Transparentność. - 2. Programowalność. - 3. Sprawozdawczość. - Wnioski.

\section{Wstęp}

Karta czy gotówka, takie pytanie stawia się przy kasie sklepowej, a może płatność dzięki aplikacji zainstalowanej w telefonie? Te lub inne dylematy natury ekonomicznej nie dotyczą jedynie zakupów, np. na potrzeby wspólnoty zakonnej, ale także wielu innych zagadnień administracji zakonnej.

Dynamiczną współczesną rzeczywistość po części ujmuje prawo kanoniczne, a więc i zakonne, które opiera się na fundamentach teologicznych. W punkcie wyjścia należy niezmiennie przywoływać przykład Jezusa, o którym św. Paweł napisał: „Znacie przecież łaskę Pana naszego Jezusa Chrystusa, który będąc bogaty, dla was stał się

\footnotetext{
${ }^{1}$ Referat został wygłoszony na Konferencji naukowej 23 października 2019 r., pt. Dobra doczesne w służbie charyzmatu i misji osób konsekrowanych (Economia a servizio del carisma e della missione), zorganizowanej przez Wydział Prawa Kanonicznego UKSW w Warszawie.
} 
ubogim, aby was ubóstwem swoim ubogacić" (2 Kor 8,9)². Uczeń Jezusa, który chce iść za swoim Mistrzem, powinien wybierać m.in. dobrowolnie ubóstwo, wyrzekając się tego, co posiada (Łk 14,25-33) oraz trzeba przywoływać słowa: „błogosławieni ubodzy w duchu, albowiem do nich należy królestwo niebieskie" (Mt 5,3)3. Taki wybór czyni człowieka wolnym wewnętrznie, bez nadmiernej troski o kwestie materialne (Mt 6,25-34; Mt 10,8-10) ${ }^{4}$.

Ubóstwo zakonne było jednym z pierwszych wyróżników tej szczególnej formy życia w Kościele. A uprzywilejowanym obrazem, na którym opierały się liczne nowe formy życia zakonnego i apostolskiego, był opis pierwotnej wspólnoty apostołów i uczniów w Jerozolimie. Członkowie wspólnoty byli zjednoczeni w modlitwie, ale także w zespoleniu posiadanych dóbr ( $\mathrm{Dz} 2,44-45)$.

Tak jak pierwotnie, tak i współcześnie, osoby i wspólnoty życia konsekrowanego przyjmują "styl życia ubogiego"5. Co to znaczy w świecie, który podlega tak dynamicznym zmianom, również w przestrzeni ekonomicznej? Aby zachować ów styl życia ubogiego w dzisiejszej administracji, koniecznymi punktami odniesienia stają się m.in. takie słowa, jak: transparentność, programowalność, sprawozdawczość. Czego dziś oczekuje Kościół od wspólnot i osób zakonnych $^{6}$ ? Jakie znaczenie nadaje tym słowom dokument Kongregacji (Economia a servizio del carisma e della missione) oraz prawo

\footnotetext{
${ }^{2}$ Cytaty biblijne za: Pismo Święte Starego i Nowego Testamentu, wyd. 3, PoznańWarszawa 1980.

${ }^{3}$ Por. Kongregacja Ds. Instytutów życia konsekrowanego i Stowarzyszeń Życia Apostolskiego, Ekonomia w służbie charyzmatu i misji. Jako dobrzy szafarze różnorakiej łaski Bożej służcie sobie nawzajem tym darem, jaki każdy otrzymał (1P 4,10). Ukierunkowania (dalej: Ekonomia w służbie charyzmatu), 12.12.2017, Wydawnictwo Ojców Franciszkanów, Niepokalanów 2019, nr 6.

${ }^{4}$ Por. tamże, nr 7.

${ }^{5}$ Tamże, nr 8.

${ }^{6}$ Treść opracowania dotyczy głównie instytutów zakonnych, jednakże w dużej mierze refleksję poniższą można zastosować do innych instytutów życia konsekrowanego oraz stowarzyszeń życia apostolskiego.
} 
powszechne Kościoła? Jak te trzy punkty odniesienia przenieść na życie zakonne? Tym pytaniom zostanie poświęcony poniższy tekst.

\section{Transparentność}

Czym jest transparentność? Ten aktualnie modny termin nie jest zakotwiczony w tradycyjnych słownikach. Drukowane encyklopedie niekiedy łączą to słowo z kosmetykami ${ }^{7}$. Najbliższy źródłowo będzie jednak „transparent”, tj. tkanina lub tablica z określonymi treściami, np. propagandowymi lub politycznymi, czy też podświetlony transparent reklamowy ${ }^{8}$. Internetowa wersja słownika języka polskiego wskazuje na takie znaczenia, jak: „«przezroczysty lub lekko przeświecający»; «łatwy do rozpoznania lub przewidzenia»; «o działaniu: jawny»"9.

Transparentna ekonomia ma być, w znaczeniu językowym, przeźroczysta, łatwa do rozpoznania, do przewidzenia i jawna w działaniu. W tym momencie nasuwają się skojarzenia $\mathrm{z}$ tekstami ewangelicznymi. Jak przykładowo: „Nie ma bowiem nic ukrytego, co by nie wyszło na jaw, ani nic tajemnego, co by się nie stało wiadome. Dlatego wszystko, co powiedzieliście w mroku, w świetle będzie słyszane, a coście w izbie szeptali do ucha, głosić będą na dachach" (Łk 12,2-3).

Słowa z Ewangelii obejmują także wspólnotę Kościoła i jego cele. Dotyczy to również celowości dóbr, jakie Kościół posiada i nimi zarządza. Sobór Watykański II, a za nim zapis w Kodeksie Prawa Kanonicznego, wskazuje na trzy ogólne ukierunkowania: organizowanie kultu Bożego, godziwe utrzymanie duchownych i innych pracowników kościelnych, prowadzenie apostolatu religijnego i charytatywnego, zwłaszcza wobec ubogich ${ }^{10}$. Te generalnie wymienione cele są

${ }^{7}$ Por. Uniwersalny słownik języka polskiego, red. S. Dubisz, t. 4, Wydawnictwo Naukowe PWN, Warszawa 2003, s. 853.

${ }^{8}$ Por. tamże.

${ }^{9}$ Transparentny: w: Słownik języka polskiego PWN, https://sjp.pwn.pl/sjp/transparentny;2578536.html [dostęp 23.08.2019].

${ }^{10}$ Por. Codex Iuris Canonici, auctoritate Joannis Pauli PP. promulgatus. Kodeks Prawa Kanonicznego. Przekład polski zatwierdzony przez Konferencje Episkopatu (dalej KPK 1983), Pallottinum, Poznań 1984, kan. $1254 \$ 2$; kan. $222 \S 1$; SoBóR 
pierwszorzędne i obejmują szereg bardziej szczegółowo określonych, również w relacji do dóbr zakonnych. Myśl ostatnich papieży mocno akcentuje potrzebę troski o ubogich, czy inaczej preferencyjnej tzw. „opcji dla ubogich”. Ojciec Święty Franciszek nieustannie przypomina o koniecznym zwróceniu się ku ubogim i potrzebującym. W Liście z okazji Roku Osób Konsekrowanych wzywał do wyjścia na tzw. peryferie życia społecznego. „Oczekuję od was także tego, o co proszę wszystkich członków Kościoła: wyjścia z siebie, aby pójść na peryferie egzystencjalne"11. Myśl tę kilkakrotnie powtarza także Kongregacja ds. Instytutów Życia Konsekrowanego i Stowarzyszeń Życia Apostolskiego ${ }^{12}$. Dobra zakonne mają służyć misji Kościoła, konkretnego instytutu, ale i najbardziej potrzebujących, którzy znajdują się w polu oddziaływania wspólnoty zakonnej ${ }^{13}$.

Każdy, kto ma udział w administracji dobrami kościelnymi, tj. także zakonnymi, winien pamiętać, że służą one przede wszystkim celom eklezjalnym ${ }^{14}$. Powracanie do tej zasady wpisuje się w transparentność myśli kościelnej. Jest to cecha, która ma przebijać i być

WATYкAŃsKi II, Dekret o posłudze i życiu kapłanów Presbyterorum ordinis, 7.12.1965, w: Sobór Watykański II, Konstytucje, Dekrety, Deklaracje, Pallottinum, Poznań 2002, s. 478-508, nr 17; A. DomaszK, Dobra doczesne Kościoła, Wydawnictwo Naukowe UKSW, Warszawa 2016, s. 72-74.

${ }^{11}$ FranciszeK, List apostolski z okazji Roku Życia Konsekrowanego, 21.11.2014, Wydawnictwo M, Kraków 2014, nr II/4.

${ }^{12}$ Por. Kongregacja Ds. Instytutów Życia Konsekrowanego i Stowarzyszeń Życia Apostolskiego, Rozpoznawajcie. Do osób konsekrowanych podążających szlakiem znaków Bożych, 8.09.2014, Wydawnictwo Sióstr Loretanek, Warszawa 2014, nr 16; TenżE, Głoście. Do osób konsekrowanych świadków Ewangelii wśród narodów, 29.06.2016, Wydawnictwo Sióstr Loretanek, Warszawa 2017, nr 77; TenżE, Młode wino, nowe bukłaki. Życie konsekrowane od Soboru Watykańskiego II i wyzwania nadal otwarte. Ukierunkowania, 3.01.2017, Wydawnictwo Sióstr Loretanek, Warszawa 2017, nr 28.

${ }^{13}$ Por. A. Domaszk, Religiosi e beni temporali - attuali indicazioni del diritto canonico, w: In Ecclesiae corde. Aspetti canonici della vita consacrata, red. J. Pudumai Doss, LAS, Roma 2019, s. 125-126.

${ }^{14}$ Por. L'amministrazione dei beni degli enti ecclesiastici tra carisma e servizio, red. F. Lozupone, San Giovanni Rotondo 2017. 
widoczna na wszelkich etapach administrowania dobrami. Dlatego „gromadzenie dóbr zbędnych nie jest i nie powinno być celem Kościoła"15.

Prawo powszechne Kościoła nakłada obowiązki i wskazuje na niektóre działania, które sprzyjają klarowności działań podmiotów kościelnych. Jednym z nich jest obowiązek przygotowywania preliminarzy budżetowych: „Usilnie zaleca się, ażeby zarządcy co roku sporządzali zestawienia przewidywanych przychodów i wydatków. Natomiast prawo partykularne może je nakazać i określić dokładniej sposoby, jak mają być sporządzane”"16. „Przygotowanie budżetu wpisuje się w racjonalne gospodarowanie, a jednocześnie w transparentność administracji, która ma realizować cele właściwe dla dóbr kościelnych"17. Szczegóły, jak wypełnić obowiązek planowania ekonomicznego, powinno określić m.in. prawo partykularne, co ma znaczenie, jeśli podmiot zakonny prowadzi np. dzieło diecezjalne. Ale podstawowym punktem odniesienia jest prawo własne instytutu zakonnego. Sporządzenie budżetu należy do poszczególnych struktur, zwłaszcza domu lokalnego, prowincji, domu generalnego, ale także chodzi o dzieła zależne od struktur zakonnych (np. szpitale, szkoły, domy opieki). Przygotowany preliminarz jest następnie sprawdzany i korygowany na wyższym poziomie zarządzania, np. plany domu zakonnego nadzorowane przez władze prowincjalne instytutu.

Kongregacja Instytutów Życia Konsekrowanego i Stowarzyszeń Życia Apostolskiego (dalej Kongregacja) poleciła w Wytycznych z 2014 r., aby oddzielać bilanse wspólnoty osób konsekrowanych od rozliczeń dzieł przez nią prowadzonych. Jak również zaleciła, aby korzystać z pomocy ekspertów oraz przeprowadzać audyty administracji zakonnej ${ }^{18}$. Odrębnie należy sporządzać plany budżetowe struktur

\footnotetext{
${ }^{15}$ A. Domaszk, Dobra doczesne Kościoła, dz. cyt., s. 62.

${ }^{16}$ KPK 1983, kan. $1284 \$ 3$.

${ }^{17}$ A. Domaszk, Dobra doczesne Kościoła, dz. cyt., s. 223.

${ }^{18}$ Por. Kongregacja Ds. Instytutów Życia Konsekrowanego i Stowarzyszeń Życia Apostolskiego, Wytyczne dotyczace zarządzania dobrami winstytutach $\dot{z} y c i a$ konsekrowanego i stowarzyszeniach życia apostolskiego. List okólny (dalej Wytyczne 2014), 2.08.2014, Wydawnictwo Sióstr Loretanek, Warszawa 2014, nr 1.3.
} 
zakonnych, a osobno prowadzonych dzieł, zależnych od podmiotów zakonnych. Choć dokumenty mogą być one w pewnej mierze łączone, razem przesyłane i kontrolowane przez struktury nadrzędne. Osoby konsekrowane nie zawsze posiadają wymaganą wiedzę ekonomiczną czy umiejętności z zakresu księgowości, stąd zalecenie Kongregacji, aby korzystać z pomocy ekspertów oraz przeprowadzać audyty, także realizowane przez instytucje zewnętrzne (biura rachunkowe itp.).

W czym jeszcze ma się zawierać transparentność administracji zakonnej? Dalsze wskazania i niektóre szczegółowe zagadnienia odnajdujemy w dokumencie z 2017 r. Ekonomia w służbie charyzmatu.

Chodzi o powiązanie ze sobą trzech zasad. „Odpowiedzialność, przejrzystość i ochrona zaufania stanowią zasady wzajemnie ze sobą powiązane: nie obdarza się odpowiedzialnością bez przejrzystości, przejrzystość wzbudza zaufanie, zaufanie potwierdza jedną i drugą" ${ }^{\prime 9}$. W dalszym rozwoju myśli, co stanowi także zobrazowanie wymienionych zasad, Kongregacja odwołuje się do obowiązku przygotowywania dokładnych i terminowych zestawień księgowych, które wymagają kontroli. Sama sprawozdawczość nie spełni swojego zadania, jeśli nie będzie weryfikowana. Gdyż „działanie ekonomiczne nie kontrolowane we właściwy sposób marnuje zasoby, sprzeciwiając się podstawowemu wskazaniu Kościoła w kwestii użytkowania dóbr

Literatura wokół dokumentu Kongregacji, por. CONGREGAZIONE PER GLI IsTITUTI di Vita Consacrata e le Società di Vita Apostolica, La gestione dei beni ecclesiastici degli Istituti di vita consacrata e delle Società di vita apostolica. A servizio dell'humanum e della missione nella Chiesa. Atti del Simposio Internazionale. Roma, 8-9 marzo 2014, Libreria Editrice Vaticana 2014; L. NAVA, A. SMERILLI, Una corretta e sana gestione. "Le Linee orientative" della CIVCSVA (2014), w: La responsabilità del Superiore Maggiore e suo Consiglio per l'amministrazione e gestione dei beni ecclesiastici, Il Calamo, Roma 2016, s. 117-149; J.I. ARriETA, Le "Linee orientative per la gestione dei beni negli Istituti di vita consacrata e nelle Società di vita apostolica", w: Povertà evangelica, missione e vita consacrata. I beni temporali negli Istituti di vita consacrata e nelle Società di vita apostolica, red. A. Aste, Marcianum Press, Venezia 2016, s. 11-28; F.G. Morrisey, Vatican Guidelines for the Administration of the Temporal Goods of Religious Institutes, w: The Temporal Goods of the Church Selected Issues, red. S. Dubiel, P. Kaleta, KUL, London 2016, s. 185-207.

${ }^{19}$ Ekonomia w służbie charyzmatu, $\mathrm{nr} 41$. 
zgodnego $\mathrm{z}$ ich przeznaczeniem, a ostatecznie w odniesieniu do dobra wspólnego (...)"20. Planowanie ekonomiczne wymaga następnie jego uzgadniania z realizacją celów dóbr zakonnych. A kontrola nadrzędna weryfikuje te założenia, ukierunkowuje aktywność na rzeczywiste cele eklezjalne i zapobiega marnotrawieniu dóbr. Odpowiedzialność wobec misji instytutu, jak również realizacja charyzmatu zakonnego, wymaga pełnienia funkcji koniecznego nadzoru i kontroli, przez powołane do tego osoby oraz struktury. Jest to służba na rzecz dobra wspólnego i wymaganej przejrzystości, która nie oznacza braku zaufania do osób podległych i ich częściowej autonomii ${ }^{21}$.

Transparentność lub inaczej przejrzystość - jak to nazywa Kongregacja - „odnosi się do umiejętności zdawania sprawy z działalności, z wyborów, z osiąganych rezultatów” oraz dalej „sprawozdania i bilanse - będące narzędziami przejrzystości - pozwalają uzyskać syntetyczny, lecz jednocześnie dokładny obraz prowadzonych działalności i ich rezultatów, kształtując u administratorów umiejętność zdawania sprawy ze swojego działania, swoich wyborów, a ogólniej ze swego postępowania"22.

Tak zarysowany sposób działania, gdy będzie utrwalony, sprzyja roztropności. Szanując każdą osobę konsekrowaną i jej dobrą wolę, nie można założyć z góry, że wszystkie decyzje natury ekonomicznej (podjęte przez zakonnika/cę) będą zawsze roztropne. Wspólne, więc i na różnych poziomach odpowiedzialności, poszukiwanie najlepszych decyzji pozwala wybrać te, które są zgodne z charyzmatem zakonnym, z eklezjalną naturą dóbr zakonnych. Ponadto, aby dokonać najlepszej oceny sytuacji, niekiedy trzeba się oddalić od obserwowanego obiektu i wówczas z pewnej perspektywy go rozeznać oraz podjąć optymalne decyzje.

Przejrzystość domaga się także sprawdzenia powodów lub motywów „decydujących o wyborach w administracji i zarządzaniu,

\footnotetext{
${ }^{20}$ Tamże.

${ }^{21}$ Por. Wytyczne 2014, nr 1.2.

${ }^{22}$ Ekonomia w służbie charyzmatu, nr 42; por. Wytyczne 2014, nr 1.2.
} 
a także właściwe zaangażowanie w udzielaniu odpowiedzi na nagłe problemy lub sytuacje krytyczne"23.

Kierując się przejrzystością, nie można zapomnieć o wymaganiach prawa państwowego, zwłaszcza, gdy chodzi o dzieła w różny sposób powiązane z tym systemem prawnym. By przywołać choćby przykłady szkół katolickich, szpitali, domów opieki czy wydawnictw. Prowadzenie takich dzieł wymaga coraz większej wiedzy specjalistycznej, kompetencji i świadomości, co do wymaganych procedur ${ }^{24}$. To, co jest transparentne w myśl własnego prawa zakonnego, nie musi być takim samym w świetle, np. prawa polskiego.

Inny przykład potrzebnej transparentności w administracji zakonnej dotyczy zdefiniowania, czym jest majątek stały instytutu i jego poszczególnych struktur. Owszem, można to zagadnienie, niezdefiniowane przez ustawodawcę, widzieć w ramach szczegółowych zagadnień zarządzania. Ale wydaje się, że jest to także kwestia przejrzystości.

Dla przypomnienia. „Stały majątek” lub stałe uposażenie osoby prawnej (stabile patrimonium) zazwyczaj stanowi to, co jest jakąś minimalną ilością majątku czy dóbr (prawnie nabytych), które są potrzebne do samodzielnego funkcjonowania i egzystencji instytucji, jak również do osiągania przez tę osobę lub instytucję własnych celów; w stopniu przynajmniej minimalnym zabezpieczają byt i działanie osoby prawnej: w dłuższym okresie czasu ${ }^{25}$. Wskazanie,

\footnotetext{
${ }^{23}$ Ekonomia w stużbie charyzmatu, nr 42.

${ }^{24}$ Por. tamże.

${ }^{25}$ Por. J.A. Renken, The Stable Patrimony of Public Juridic Persons, The Jurist 70 (2010), z. 2, s. 131-162; P. KAleta, Pojęcie patrimonium stabile, Roczniki Nauk Prawnych 24 (2014), nr 4, s. 147-161; TEnże, Kościelne prawo majątkowe, Towarzystwo Naukowe KUL, Lublin 2014, s. 58-61; A. Domaszk, Dobra doczesne Kościoła, dz. cyt., s. 252-254; C.E. VARALDA, L'istituto del patrimonio stabile tra norme canoniche e disciplina concordataria per L'Italia, Ephemerides Iuris Canonici 55 (2015), z. 2, s. 467-502; V. De Paolis, Il Codice del Vaticano II. I beni temporali della Chiesa, EDB, Bologna 2001, s. 185-188; V. MoscA, "Il patrimonio stabile” nota dell'area giuridica CISM, w: La responsabilità del Superiore Maggiore e suo Consiglio per l'amministrazione e gestione dei beni ecclesiastici, Il Calamo, Roma 2016, s. 77-116.
} 
co jest stałym majątkiem należy do kompetencji zwierzchniej władzy kościelnej, która decyduje o prawnym przeznaczeniu dóbr albo jest też powiązane z zapisami norm prawa partykularnego czy sformułowaniami statutowymi. Kompetentny przełożony podejmuje decyzję o wydzieleniu dóbr stanowiących stałe patrymonium osoby prawnej, co stwierdza w formie dekretu, w którym wyszczególnia, jakie to są dobra; tego rodzaju dokument przełożonego jest aktem nadzwyczajnej administracji. Do patrymonium nie przynależą te dobra, które są związane z codzienną administracją, z potrzebami życia codziennego, czy aktualne wpływy ${ }^{26}$.

Chociaż z jednej strony można postawić ostrożną tezę, że niektóre osoby prawne publiczne w Kościele mogą osiągać własne cele oraz istnieć bez określenia, co jest dla nich stałym patrymonium, czy nawet bez faktycznego posiadania znaczniejszych dóbr. Przykładowo, jeśli erygowany dom zakonny dzierżawi jakiś budynek, mieszkanie lub nieruchomość, a bieżące funkcjonowanie domu zabezpieczają ofiary wiernych, czy dobra fundacji, odrębnej od struktur zakonnych. Albo też, gdy właścicielem nieruchomości jest prowincja zakonna, a nie określony dom zakonny, który nie posiada odrębnych dóbr, jakie można by zakwalifikować pod pojęciem stałego majątku ${ }^{27}$.

To jednakże, z drugiej strony, Magisterium Kościoła poleca, aby $\mathrm{w}$ instytutach zakonnych dokonano zestawienia i wydzielenia tych dóbr, które należą do patrymonium. Na ten temat Kongregacja wypowiedziała się w Wytycznych z 2014 r. Zalecono, aby każdy instytut zadbał o dokonanie spisu dóbr, tworzących stały majątek, a także by wyższy przełożony lub organ kolegialny - w formie uchwały - zatwierdził prawne nabycie majątku oraz wprowadzono odpowiedni zapis pojęcia majątek stały w konstytucjach lub innym zbiorze prawa własnego $^{28}$. Dyspozycje zostały ponowione i uszczegółowione w dokumencie Ekonomia w stużbie charyzmatu. Między innymi wska-

\footnotetext{
${ }^{26}$ Por. T. Pawluk, Prawo kanoniczne według Kodeksu Jana Pawła II. Dobra doczesne Kościoła. Sankcje w Kościele. Procesy, t. 4, WWD, Olsztyn 1990, s. 50.

${ }^{27}$ Por. A. Domaszk, Dobra doczesne Kościoła, dz. cyt., s. 254.

${ }^{28}$ Por. Wytyczne 2014, nr 1.4 .
} 
zano na grupy dóbr, które powinny przynależeć do stałego majątku instytutu lub stowarzyszenia ${ }^{29}$.

Jednoznaczność w określeniu, co jest, a co nie jest majątkiem stałym rzutuje na dalsze decyzje ekonomiczne. Zgodnie z prawem kodeksowym, zarządca kościelnej osoby prawnej nie może dokonać darowizny z dóbr, które przynależą do patrymonium tej osoby ${ }^{30}$. Następnie chodzi o kwestię alienacji. Dla dokonania ważnej alienacji dóbr przypisanych do stałego majątku konieczna jest zgoda odpowiedniej władzy kościelnej, na co wpływa również wartość (suma) alienowanego majątku: „Dla dokonania ważnej alienacji dóbr stanowiących stały prawnie nabyty majątek publicznej osoby prawnej, których wartość przekracza określoną w prawie sumę, wymagane jest zezwolenie kompetentnej władzy, zgodnie z przepisami prawa" ${ }^{31}$. Nie rozwijając w tym miejscu szerokiego tematu pojęcia alienacji ${ }^{32}$, należy jednak podkreślić, że decyzje wyróżnienia stałego majątku przekładają się na klarowność, czyli na transparencję tego, kto i w jakim

${ }^{29}$ Por. Ekonomia w służbie charyzmatu, nr 38-40.

${ }^{30}$ Por. KPK 1983, kan. 1285.

31 Tamże, kan. 1291.

${ }^{32}$ Por. E. Sztafrowski, Podręcznik prawa kanonicznego, t. 4, ATK, Warszawa 1986, s. 293-294; W. Wójcıк, Dobra doczesne Kościoła, w: Wójcik W., Krukowski J., Lempa F., Komentarz do Kodeksu Prawa Kanonicznego, t. 4, Redakcja Wydawnictw KUL, Lublin 1987, s. 86; L. Chiappetta, Il Codice di diritto canonico. Commento giuridico-pastorale, t. 2, 3 ed., EDB, Bologna 2011, s. 590; V. DE PAOLIs, Il Codice del Vaticano II..., dz. cyt., s. 188-189; C. BEGUs, Diritto patrimoniale canonico, Città del Vaticano 2007, s. 214-217; L. Świto, Alienacja majątku kościelnego $w$ diecezjach rzymsko katolickich w Polsce, SQL, Olsztyn 2010, s. 89-92; S. DuBIEL, Uprawnienia majątkowe Kościoła Katolickiego w Polsce w świetle Kodeksu Prawa Kanonicznego z 1983 r., Konkordatu z 1993 r. i ustaw synodalnych, KUL, Lublin 2007, s. 72-73; A. Domaszk, Dobra doczesne Kościoła, dz. cyt., s. 247-272; P. Kaleta, Kościelne prawo majątkowe, dz. cyt., s. 204-206; V. PAlestro, La disciplina canonica in materia di alienazioni e di locazioni (can. 1291-1298), w: I beni temporali della Chiesa (Studi Giuridici L), Città del Vaticano 1999, s. 148-149; S. Ridella, La validità alienazione dei beni ecclesiastici. Uno studio a partire dai cann. 1291-1292, LAS, Roma 2010. 
zakresie - w ramach prawa kanonicznego - podejmuje (może podjąć) ważne decyzje o alienacji.

Uchwały na temat stałego majątku oraz decyzje dotyczące alienacji mają także swoje odniesienie do prawa państwowego. W niektórych przypadkach umowy cywilno-prawne znajdują swój finał w sądach polskich, kiedy na tym forum sięga się po przepisy wewnętrzne Kościołów i związków wyznaniowych; w tym do prawa własnego i decyzji administracyjnych w przestrzeni majątkowej. Ich istnienie lub brak rzutuje na klarowność albo niejasność sytuacji prawnej majątku kościelnego ${ }^{33}$. A poza kontekstem alienacji, wspomnieć jeszcze trzeba o wypełnianiu rozliczeń, gdy takie obowiązki nakłada prawo państwowe, choćby w kontekście prowadzonych dzieł edukacyjnych, opiekuńczych, zdrowotnych itd. Sumienna dokumentacja, przygotowana po stronie instytutu, usuwa podejrzenia i niejasności, co do finansowania dzieł zakonnych.

Powyższe rozważania na temat transparencji administracji zakonnej mogą rodzić pytania, czy poszczególne instytuty dostosowały się do wymagań Magisterium Kościoła. Nie przesądzając, jaka jest odpowiedź, należy jednak „inicjować procesy”. To ostatnie sformułowanie podaje nam Kongregacja, podążając za myślą papieża Franciszka ${ }^{34}$. Chodzi o rozpoczynanie procesów w przestrzeni ekonomicznej, w tym o tzw. myślenie projektowe. Charyzmaty zakonne przyjmują postać konkretnych działań o długofalowym oddziaływaniu. Aby wiernie postępować, według posiadanych darów charyzmatycznych, należy idee przełożyć na projektowanie konkretnych poczynań. Klarowność, która rozpoczyna się na najniższym stopniu administracji dobrami zakonnymi, pozwala tworzyć większą wartość, gdzie „całość przewyższa część”35. To znaczy także, że projekty instytutu współgrają z programami Kościołów lokalnych i w całości stanowią realizację celów Kościoła powszechnego. Myślenie projektowe pozwala na jasność czy przejrzystość zarządzania, co oznacza odchodzenie od

\footnotetext{
${ }^{33}$ Por. A. Domaszk, Dobra doczesne Kościoła, dz. cyt., s. 273-278.

${ }^{34}$ Por. Ekonomia $w$ służbie charyzmatu, nr 46.

${ }^{35}$ Por. tamże, nr 48.
} 
spontanicznych działań o nieprzewidywalnym efekcie. W ten sposób zwiększa się też świadomość członków instytutu, w jakim punkcie się znajdują, co mogą uczynić i dokąd zmierzają.

Przejrzystość ekonomii zakonnej opiera się na określonych fundamentach. Dokument Kongregacji przypomina o powracaniu do podstawy wierności Bogu i Ewangelii, wierności charyzmatowi, ubóstwu, poszanowaniu kościelnej natury dóbr, stabilności dzieł oraz konieczności zdawania sprawy z zarządu ${ }^{36}$.

\section{Programowalność}

Czym jest programowalność lub programowanie? Te terminy współcześnie jakby bardziej mają konotację ze światem nowych technologii informatycznych. Tym niemniej można też mówić o programowaniu w innych kontekstach znaczeniowych, w tym i ekonomicznym. Zbliżonym słowem jest „planowanie”. Jeden ze słowników języka polskiego opisuje termin, pochodzący od rzeczownika: planować (np. „planować budżet na przyszły rok”) ${ }^{37}$, w następujący sposób: „(...); Planowanie gospodarcze ‘określanie przyszłych celów i zadań ekonomicznych oraz sposobu ich realizacji' "38. W encyklopediach występuje termin: „planowa gospodarka” ${ }^{39}$ lub „planowanie gospodarcze" ${ }^{\prime 0}$, co oznacza, że np. w aktualnej polskiej rzeczywistości - gospodarki rynkowej - państwo posiada instrumenty indykatywne, kierunkujące i wpływające na procesy ekonomiczne.

Zarządzanie dobrami kościelnymi w ramach instytutu czy stowarzyszenia nie może pominąć planowania, więc określania celów, zadań i sposobu ich realizacji. Choć ewidentnym jest, że cele dóbr zakonnych nie mogą być nastawione zasadniczo na zysk ekonomiczny,

\footnotetext{
${ }^{36}$ Por. tamże, nr 51.

${ }^{37}$ Por. Uniwersalny Słownik Języka Polskiego, red. S. Dubisz, t. 3, Wydawnictwo Naukowe PWN, Warszawa 2003, s. 479.

${ }^{38}$ Tamże.

${ }^{39}$ Por. Ł. Czuma, Planowa gospodarka, w: Encyklopedia Katolicka, t. 15, red. S. Wilk, Towarzystwo Naukowe KUL, Lublin 2011, kol. 790-791.

${ }^{40}$ Por. Planowanie gospodarcze, w: Encyklopedia PWN, https:/encyklopedia.pwn. $\mathrm{pl} /$ haslo/planowanie-gospodarcze;4009528.html [dostęp 28.08.2019].
} 
tak jak innych podmiotów obrotu gospodarczego. Ponadto w oczywisty sposób działanie zaplanowane - w myśli chrześcijańskiej łączy się z cnotą roztropności, która odnosi się do sądów sumienia i stosowania zasad moralnych. „Roztropność jest cnotą, która uzdalnia rozum praktyczny do rozeznawania w każdej okoliczności naszego prawdziwego dobra i do wyboru właściwych środków do jego pełnienia" 41 .

Kościół jako społeczność, w której występuje element ludzki oraz Boski, nie może zaniedbać tego, co nazywa się odczytywaniem woli Bożej. Zatem, z jednej strony, programowanie ekonomiczne oparte tylko na ludzkich kalkulacjach nie jest chrześcijańskim rozeznawaniem. Jednakże $\mathrm{z}$ drugiej strony przesuwanie akcentu w poczynaniach, kiedy mocniej/jedynie wskazuje się na Opatrzność Bożą, a zaniedbuje czynnik ludzkiego planowania, też nie jest do przyjęcia. W myśli katolickiej, wychodząc od stwierdzenia, że Bóg jest niezależnym Władcą swego zamysłu, to jednak wskazuje się, iż On dopuszcza człowieka do współudziału, do godnego, rozumnego i samodzielnego działania ludzkiego ${ }^{42}$. Nie można lekceważyć ani wykluczać ludzkiego myślenia rozumowego, czy przyjmować postawy, którą się nazywa: „jakoś to będzie”, w zakresie programowania ekonomicznego. A autorzy dokumentu Ekonomia w stużbie charyzmatu stwierdzają: „Należy przezwyciężać mentalność, według której projektowanie i planowanie działalności i dzieł przeciwstawiane jest otwartości na nowość Ducha Świętego. Przeciwnie, wiele intuicji nie ujrzało światła dziennego, ponieważ nie zostały oparte na programie i/lub planowaniu: nie określono celów, nie wyodrębniono form realizacji ani nie zweryfikowano zgodności ekonomiczno-finansowej" ${ }^{43}$. Projektowanie i planowanie w żaden sposób nie jest odstępowaniem od ideałów, ograniczeniem kreatywności czy brakiem zawierzenia Opatrzności Bożej; przeciwnie, koncepcyjna ekonomia służy zamysłom charyzmatycznym ${ }^{44}$.

\footnotetext{
${ }^{41}$ Katechizm Kościoła Katolickiego, wyd. 2, Pallottinum, Poznań 2002, nr 1806.

${ }^{42}$ Por. tamże, nr 306-308.

${ }^{43}$ Ekonomia $w$ służbie charyzmatu, nr 35.

${ }^{44}$ Por. tamże.
} 
Programowanie działań ekonomicznych, zanim zostanie ujęte w szczegółowe zapisy, najpierw wymaga przyjęcia myślenia projektowego. Poczynając od rozważenia przez wszystkich odpowiedzialnych w instytucie, jakie ukierunkowania są możliwe. W perspektywie szerszej, nie tylko „naszego ciasnego ogródka”; i nie tylko, jako podtrzymanie ciągłości dzieł, ile poprzez ich reorganizację na rzecz istotnej obecności społecznej oraz zakonnej ${ }^{45}$. Aby „wizję przyszłości instytutu przełożyć na konkrety, poprzez strategiczny plan pracy, który wykorzystuje wspólne drogi" ${ }^{46}$.

W myśleniu projektowym, zgodnie z już przywołaną zasadą: „całość przewyższa część" ${ }^{47}$, plany różnych struktur instytutu są w relacji do poczynań całego instytutu. Jak również powinny nawiązywać do misji Kościoła powszechnego i lokalnego. Szanując autonomię zakonną, nie można pomijać diecezjalnych programów duszpasterskich oraz konsultacji z biskupami, aby komunia braterstwa i wspólnego działania przeważała nad partykularyzmami ${ }^{48}$. „Działanie razem wymaga również koordynacji i współuczestnictwa na poziomie planowania i zarządzania, mentalności, kultury i praktyk, które, jeśli byłyby poważnie realizowane, niemałej liczbie dzieł mogłyby zapewnić ciągłość, skuteczność ewangeliczną oraz stabilność ekonomiczną"49.

Zarysowane wyżej wskazania Magisterium prowadzą do tego, aby inicjować procesy, co już wyżej przywołano, także jako programowanie ekonomiczne. Planowanie musi jednakże uwzględniać rzeczywistość, taką, jaka ona jest. Autorzy dokumentu ujmują powyższą myśl we frazie: „rzeczywistość przewyższa idee” ${ }^{50}$. Chodzi o projektowanie realne, rzeczywiste, o przechodzenie od „słuchania życia”, poprzez intuicje duchowe, do wdrożenia konkretnych projektów. „Dzieła naszych instytutów rodzą się ze słuchania Boga i mają odpowiadać na

\footnotetext{
${ }^{45}$ Por. tamże, nr 26-27; Wytyczne 2014, nr 1.1.

${ }^{46}$ Ekonomia w stużbie charyzmatu, nr 26.

${ }^{47}$ Por. tamże, nr 48.

${ }^{48}$ Por. tamże, nr 29-32, 48; Wytyczne 2014, nr 2.1.

${ }^{49}$ Ekonomia w stużbie charyzmatu, nr 33.

${ }^{50}$ Tamże, nr 47.
} 
potrzeby konkretnych osób. Nie rodzą się z abstrakcyjnych projektów tworzonych przy stoliku, lecz jako konkretna odpowiedź na potrzeby realnych osób, z znajomością ich życia, historii, trudności"51.

W tym miejscu rozważania dotyczące programowania należy odnieść do niektórych wskazań, wynikających z kanonicznego prawa powszechnego, a rozszerzonych w dokumencie z 2017 r. Jednymi z kluczowych są słowa: nadzór i zezwolenie, powiązane $\mathrm{z}$ różnymi etapami planowania ekonomicznego ${ }^{52}$.

Określone podmioty władzy w Kościele pełnią nadzór nad strukturami podrzędnymi. Poczynając od papieża ${ }^{53}$, przez Kongregację ${ }^{54}$, do struktur instytutu. Do Kapituły Generalnej należy przygotowanie planów charyzmatycznych, dyrektoriów ekonomicznych; a konkretne decyzje operacyjne są w kompetencji przełożonego generalnego $\mathrm{z}$ jego radą ${ }^{55}$. Następnie trzeba wskazać na dalszych przełożonych zakonnych (różnych stopni), z ich organami doradczymi i kapituły prowincjalne ${ }^{56}$.

Prawo powszechne akcentuje szczególną rolę ordynariusza. „Do ordynariusza należy pilnie nadzorować zarząd wszystkich dóbr, należących do podległych mu publicznych osób prawnych, z zachowaniem prawnych tytułów przyznających mu większe uprawnienia" ${ }^{57}$. W ramach nadzoru, ordynariusz (prowincjał zakonny) dokonuje wizytacji i inspekcji, przegląda sprawozdania finansowe i żąda ich

\footnotetext{
${ }^{51}$ Tamże.

${ }^{52}$ Por. Wytyczne 2014, nr 1.2.

${ }^{53}$ Por. KPK 1983, kan. 1273; Ekonomia w służbie charyzmatu, nr 56.

${ }^{54}$ Por. Joannes Paulus II, Constitutio apostolica de Romana Curia Pastor Bonus, 28.06.1988, AAS 80 (1988), s. 841-912; tekst polski w: Ustrój hierarchiczny Kościoła. Wybór źródeł, red. W. Kacprzyk, M. Sitarz, Wydawnictwo KUL, Lublin 2006, s. 217-257, art. $108 \$ 1$; Ekonomia w służbie charyzmatu, nr 57.

${ }^{55}$ Por. KPK 1983, kan. $631 \S 1$; Ekonomia $w$ służbie charyzmatu, nr 58.

${ }^{56}$ Por. KPK 1983, kan. 617-633; Ekonomia w służbie charyzmatu, nr 59-60; L. SABBARESE, Elementi imprescindibili della responsabilità del superiore maggiore e suo consiglio per l'amministrazione e gestione dei beni, w: La responsabilità del Superiore Maggiore e suo Consiglio per l'amministrazione e gestione dei beni ecclesiastici, Il Calamo, Roma 2016, s. 37-76.

${ }^{57}$ KPK 1983, kan. $1276 \S 1$; por. tamże, kan. 134.
} 
przedstawienia, ustanawia normy dotyczące administracji dobrami. Prawo nadzoru można też podzielić na: uprzednie (żądanie preliminarza, uzyskiwanie zgody i zezwolenia od ordynariusza) oraz następcze (sprawozdania, protokoły, kontrole, pouczenia itp.) ${ }^{58}$.

Niekiedy nadzór wykracza poza kompetencje wewnętrzne i prawo powszechne wskazuje na uprawnienia biskupa diecezjalnego lub ordynariusza miejsca. „Klasztory niezależne, o których w kan. 615, powinny raz w roku składać sprawozdanie z zarządu ordynariuszowi miejsca. Ponadto ordynariuszowi miejsca przysługuje prawo wglądu w sprawy gospodarcze domu zakonnego na prawie diecezjalnym"59.

Prawo powszechne Kościoła znacząco wskazuje na tematykę pozyskiwania odpowiednich zezwoleń, wymaganych w administracji dobrami kościelnymi, tj. także zakonnymi. A to w istotny sposób łączy się z programowaniem i przygotowywaniem różnych planów ekonomicznych, co także zawiera treść dokumentu Ekonomia w słuzbie charyzmatu w rozdziale: Wytyczne operacyjne. Kongregacja wydaje konieczne zezwolenia, w przypadkach przewidzianych przez prawo: „Do ważności alienacji i jakiegokolwiek działania, przez które stan majątkowy osoby prawnej może doznać uszczerbku, potrzebne jest pisemne zezwolenie kompetentnego przełożonego, wydane za zgodą jego rady. Jeśli natomiast chodzi o transakcje, w których suma przekracza wysokość określoną dla danego regionu przez Stolicę Apostolską, albo przedmiotem są dobra ofiarowane Kościołowi na mocy ślubu albo rzeczy drogocenne $\mathrm{z}$ racji artystycznych lub historycznych, potrzebna jest ponadto zgoda Stolicy Świętej" ${ }^{\prime 0}$. Istotą takiego zezwolenia jest potwierdzenie, że już dokonane i dalsze czynności są zgodne z właściwym przeznaczeniem majątku kościelnego ${ }^{61}$.

${ }^{58}$ Por. A. Domaszk, Dobra doczesne Kościoła, dz. cyt., s. 186-192; P. Kaleta, Władza nadzorowania zarządzaniem dobrami kościelnymi (kan. 1276 \$ 1-2), Kościół i Prawo 17(2015) 2, s. 25-66.

${ }^{59}$ KPK 1983, kan. 637; por. tamże, kan. $392 \$ 2$.

${ }^{60}$ Tamże, kan. $638 \$ 3$. Por. A. Domaszk, Dobra doczesne Kościoła, dz. cyt., s. 251-265.

${ }^{61}$ Por. Ekonomia w służbie charyzmatu, nr 57. Zgoda usuwa kanoniczną przeszkodę, ale nie oznacza odpowiedzialności Stolicy Apostolskiej za czynności 
Chodzi o czynności, które wpisują się w klasycznie rozumiane pojęcie alienacji: sprzedaż, darowizna, zamiana; kiedy zgoda Kongregacji jest wymagana, o ile transakcja przekracza górny limit sumy (dla regionu); nawet niezależnie od tego, czy dobra są formalnie przypisane do stałego majątku62. Ale wyraźnie pojawiają się dodatkowe wymagania, o które należy zadbać na etapie planowania. Takie jak: przeprowadzenie odpowiednich procedur wewnątrz instytutu, zgodnie $z$ prawem własnym; dokumentacja rzeczoznawcy; opinia ordynariusza miejsca, gdy sprawa dotyczy instytutu na prawie papieskim; zgoda ordynariusza miejsca, względem instytutu na prawie diecezjalnym i klasztoru niezależnego; wykonanie odpowiedniego ekonomiczno-finansowego planu naprawczego, jeśli trzeba spłacić długi instytutu; dodatkowe zastrzeżenia dotyczą nieruchomości położonych w Rzymie, na Malcie i na Środkowym Wschodzie ${ }^{63}$.

Zgoda Stolicy Apostolskiej dotyczy następnie rzeczy drogocennych $z$ racji artystycznych lub historycznych oraz darów wotywnych ${ }^{64}$. Także, gdy rzeczone dobra nie przekraczają górnej granicy ustalonej dla regionu sumy. Absolutnie niedopuszczalna jest nadto sprzedaż relikwii.

Z kolei w szerokim rozumieniu pojęcia alienacji, Stolica Apostolska wydaje zezwolenia na ewentualne korzystanie z kredytów, aby sfinansować operacje, przekraczające najwyższą sumę, określoną dla regionu kościelnego ${ }^{65}$. Również zezwolenie Kongregacji jest konieczne - powyżej najwyższej sumy - na dzierżawę, użyczenie, użytkowania,

cywilno-prawne; tę odpowiedzialność ponosi podmiot będący stroną w umowie, por. A. Domaszk, Dobra doczesne Kościoła, dz. cyt., s. 258.

${ }^{62}$ Por. Ekonomia w służbie charyzmatu, nr 81.

${ }^{63}$ Treść dokumentu Ekonomia $w$ służbie charyzmatu przypomina także inne wymagania prawa powszechnego, jak konieczność zezwolenia, gdy niektóre części dóbr podzielnych były już wcześniej alienowane; sprzedaż większej ilości dóbr, gdy ich łączna wartość przekracza górną sumę, por. tamże, nr 81; KPK 1983, kan. 1292 $\S 2-3$.

${ }^{64}$ Por. Ekonomia w służbie charyzmatu, nr 81.

${ }^{65}$ Por. tamże, nr 71 . 
zamieszkania i inne podobne umowy cywilno-prawne, gdy czas umowy będzie wiązać ponad dziewięć lat ${ }^{66}$.

Programowanie ekonomiczne nie zawsze ociera się o górne kwoty ustalone dla regionów kościelnych. Trudno w tym miejscu znaleźć wspólne zapisy dla wszystkich instytutów zakonnych. Należy jedynie przypomnieć, że prawo własne powinno sprecyzować uprawnienia i kompetencje, przypisane do poszczególnych stopni sprawowania władzy, ze szczególnym uwzględnieniem nadzwyczajnych aktów administracji, w tym także tych o charakterze alienacji ${ }^{67}$. Planowanie musi uwzględniać dyrektywy prawa własnego. A każde przekroczenie zakresu uprawnień, zwyczajnej administracji, czy limitów kwotowych, np. ustalonych w instytucie dla prowincji zakonnej, wymaga uzyskania uprzedniego zezwolenia władzy zwierzchniej ${ }^{68}$. Jest to odpowiedzialność poszczególnych przełożonych, których wspiera własna rada. Ponadto, dokument z 2017 r. poleca powoływanie dodatkowych organów konsultacyjnych: zespołów do spraw ekonomicznych, złożonych również z osób świeckich, posiadających wiedzę specjalistyczną. „Przełożony, w którego kompetencji leży zezwalanie na nadzwyczajne akty administracyjne, poza zgodą swojej Rady (por. kan. $627 \$ 1$ ) uzyska również opinię (por. kan. $127 \$ 22^{0}$ ) Rady do spraw ekonomicznych" ${ }^{6}$.

W ramach kompetencji wynikających z prawa własnego, swoje obowiązki wypełnia ekonom i jego współpracownicy. Przekroczenie zwyczajnej administracji wymaga pozyskania zezwolenia od właściwego przełożonego. Niekiedy akty prawne w imieniu instytutu dokonuje przedstawiciel prawny (osoby trzecie); również on potrzebuje uprzedniego zezwolenia na czynności przekraczające zwyczajny zarząd $^{70}$.

\footnotetext{
${ }^{66}$ Por. tamże, nr 78.

${ }^{67}$ Por. tamże, nr 59.

${ }^{68}$ Por. tamże, nr 60; A. Domaszk, Dobra doczesne Kościoła, dz. cyt., s. 207-208.

${ }^{69}$ Ekonomia w stużbie charyzmatu, nr 61.

${ }^{70}$ Por. tamże, nr 65.
} 
Programowanie ekonomiczne w dużej mierze zbiega się z przygotowywaniem preliminarzy budżetowych, na każdym poziomie sprawowania władzy ${ }^{71}$. Temat ten był już zasygnalizowany w poprzednim punkcie tego opracowania. Nie chodzi tylko o plany na kolejny rok rozliczeniowy. Niektóre projekty, w tym te dotyczące zarządu nadzwyczajnego, czy alienacji, wymagają planowania wieloletniego. „Konieczne jest zatem, by instytuty życia konsekrowanego (...) opracowały długoterminowe plany i prognozy, by jak najszybciej zapobiegać powstawaniu problemów lub stawić im czoło, dopóki sytuacja jest jeszcze możliwa do opanowania"72. I analogicznie do krótkookresowych planów, wymagają pozyskania zezwolenia od kompetentnych władz instytutu, niekiedy instytucji powiązanych z dziełem, zgody lub opinii ordynariusza miejsca (np. w przypadku prowadzenia dzieł diecezjalnych), czy w określonych sytuacjach: Stolicy Apostolskiej.

Plany długotrwałe, ze względu na zmianę warunków zewnętrznych, jak choćby ceny materiałów i usług, z czasem domagają się przeprowadzenia ponownej waloryzacji projektów. Zaleca się, aby instytuty „wprowadziły odpowiednie systemy monitorowania dzieł podupadających, wdrażały plany wychodzenia z deficytu i przezwyciężały mentalność opiekuńczą: pokrycie strat danego dzieła bez rozwiązywania problemów związanych z jego zarządzaniem oznacza marnotrawstwo środków, które mogłyby być wykorzystane w innych dziełach"73. Ponadto w programowaniu należy uwzględniać ewentualne zagrożenia i ryzyka dla projektów. Roztropne szacowanie ryzyka pomaga efektywnie doprowadzić projekty do końca, np. poprzez zabezpieczenie dodatkowych środków, czy ubezpieczenie w instytucjach zewnętrznych. Przy planowaniu nie można zapomnieć o nadrzędnym celu Kościoła, a więc także o etycznym elemencie projektów. II Polski Synod Plenarny postuluje, aby Kościół, więc i publiczne

${ }^{71}$ Por. A. Domaszk, Dobra doczesne Kościoła, dz. cyt., s. 223-224; P. Kaleta, Kościelne prawo majątkowe, dz. cyt., s. 169-170.

${ }^{72}$ Wytyczne 2014, nr 1.1 .

${ }^{73}$ Tamże. 
osoby prawne instytutu w działaniach ekonomicznych stawiały sobie większe wymogi etyczne, niż inni zarządcy ${ }^{74}$.

\section{Sprawozdawczość}

Czym jest sprawozdawczość? Jeden ze słowników języka polskiego ujmuje znaczenie tego terminu następująco: „'opracowanie sprawozdań, całokształt prac sprawozdawczych'; 'sprawozdawczość, gospodarcza, bankowa' "75. Czy tak zdefiniowana, czy jeszcze inaczej ujęta sprawozdawczość stanowi jakby drugą klamrę spajającą działania i projekty ekonomiczne. Na początku zaplanowane, na końcu domagają się podsumowania, ujęcia sumarycznego, ze wskazaniem pozytywów i negatywów przeprowadzonego działania, projektu czy postępowania.

Treść dokumentu Kongregacji Ekonomia w służbie charyzmatu, odnosząc się do potrzeby transparentności i planowania, domaga się od osób odpowiedzialnych koniecznego nadzoru i kontroli, m.in. w odniesieniu do dokładnych i terminowych zestawień księgowych ${ }^{76}$. Brak właściwej kontroli marnuje zasoby zakonne i ostatecznie sprzeciwia się wskazaniom Kościoła odnośnie do użytkowania dóbr, zgodnie z ich przeznaczeniem oraz dobrem wspólnym.

Dobrze wykonana sprawozdawczość wzmacnia wiarygodność i zaufanie. I nie chodzi tu jedynie o wymiar wewnątrz-zakonny, ale również prowadzi do dawania na zewnątrz świadectwa osobistego i wspólnotowego, a ponadto „kultura i praktyka przejrzystości nie mogą być oddzielane od wierności własnej historii i tradycji charyzmatycznej związanej ze ślubem ubóstwa ani od zrównoważonych przepisów dotyczących zależności i ograniczenia w używaniu dóbr i dysponowania nimi (por. kan. 600)"77. Konieczność zdawania relacji

\footnotetext{
${ }^{74}$ Por. II Polski Synod Plenarny (1991-1999), Kościół wobec życia społeczno-gospodarczego, Pallottinum, Poznań 2001, s. 65-81, nr 55.

${ }^{75}$ Uniwersalny Słownik Języka Polskiego, red. S. Dubisz, t. 4, Wydawnictwo Naukowe PWN, Warszawa 2003, s. 490.

${ }^{76}$ Por. Ekonomia w służbie charyzmatu, nr 41; Wytyczne 2014, nr 1.3.

${ }^{77}$ Ekonomia $w$ służbie charyzmatu, nr 43; Wytyczne 2014, nr 1.1.
} 
z przeprowadzonych czynności pokazuje nie tylko liczby, ale również, jakie wybory towarzyszyły działaniom, czym się kierowały zainteresowane osoby, ich dokonania i ostatecznie rezultaty, również w perspektywie wierności charyzmatowi zakonnemu ${ }^{78}$.

Sprawozdawczość opiera się na wytycznych płynących z prawa powszechnego i prawa własnego. Kongregacja zwraca uwagę na to, że jednym $\mathrm{z}$ wewnętrznych narzędzi jest przyjęty przez przełożonego, wraz z jego radą, Regulamin administracyjny, zawierający szczegółowe wskazania operacyjne, w powiązaniu z zakonnym planem charyzmatycznym i dyrektorium ekonomicznym. Kontrola, a więc i wszystkie konieczne sprawozdania, dotyczą struktur instytutu oraz dzieł z nim powiązanych. „Powinno się także zapewnić, by ci, którzy zostali instytucjonalnie powołani do sprawowania kontroli, okresowo informowali kompetentnego przełożonego o wyniku swoich działań"79. Prawo własne instytutu powinno określić różne formy kontroli wewnętrznej, których częścią są sprawozdania. Tak, aby w imieniu Kościoła nadzorować poczynania ekonomów, przedstawiciela prawnego, czy zaangażowanych specjalistów ${ }^{80}$.

Ogólny obowiązek sprawozdawczości wymaga stosowania zasady proporcjonalności. Przekazana informacja opiera się na prowadzonej dokumentacji, głównie w księgach ekonomicznych. To tradycyjne rozwiązanie: pisemnej dokumentacji nie wyklucza, a wręcz domaga się zastosowania nowych rozwiązań informacyjnych: „posługiwać się nowoczesnymi komputerowymi systemami archiwizacji i przechowywania danych" "1. Tak, aby z ich pomocą móc zidentyfikować dane majątkowe oraz finansowe poszczególnych wspólnot i dzieł ${ }^{82}$.

\footnotetext{
${ }^{78}$ Por. Ekonomia w stużbie charyzmatu, nr 51.

${ }^{79}$ Tamże, nr 62. „Opracować odpowiednie systemy kontroli wewnętrznej, dostosowane do rozmiarów dzieł, w oparciu o odpowiedni podział obowiązków i jasny system pozwoleń", Wytyczne 2014, nr 1.2.

${ }^{80}$ Por. Ekonomia w służbie charyzmatu, nr 67; KPK 1983, kan.1282, w powiązaniu z kan. 1258: „w imieniu Kościoła” - oznacza w imieniu kościelnej publicznej osoby prawnej, czyli np. domu lub prowincji zakonnej.

${ }^{81}$ Wytyczne 2014, nr 1.2 .

${ }^{82}$ Por. Ekonomia w służbie charyzmatu, nr 91.
} 
A jeśli instytut prowadzi działalność w wielu krajach, to należy dobrać takie narzędzia sprawozdawczości: programy księgowe, aby móc dokonywać zestawień wspólnych oraz łączyć dane ekonomiczne, na szczeblu krajowym i międzynarodowym ${ }^{83}$.

Zasadą powinno być prowadzenie dokumentacji księgowej osobno dla poszczególnych dzieł; a rozbudowane dzieła poddawać się powinno audytowi zewnętrznemu ${ }^{84}$, czy okazjonalnie, czy okresowo. W celu dobrego wykorzystania posiadanych zasobów należy przygotować planowanie długookresowe (planowanie strategiczne), coroczne programowanie ekonomiczno-finansowe (budżet), dokonywanie bieżącej weryfikacji oraz sprawdzanie osiąganych celów (kontrola zarządzania) ${ }^{85}$.

Wewnętrzna kontrola w instytucie, jakby idąc hierarchicznie w górę, pozwala przygotować całościowe sprawozdanie na potrzeby Kongregacji, jako okresowe zestawienia: „W celu zacieśnienia wspólnoty instytutów ze Stolicą Apostolską, każdy najwyższy przełożony ma obowiązek - w sposób i w czasie przez nią określonym - przesyłać do Stolicy Świętej krótkie sprawozdanie dotyczące stanu i życia instytutu" 86 . Okresowe sprawozdanie pokazuje dane, ale również ogólnie kondycję instytutu, przewidywane zmiany, co nawet może mieć przełożenie na ewentualny dialog dyplomatyczny Stolicy Apostolskiej z poszczególnymi państwami ${ }^{87}$. Jeśli ze sprawozdań wyłaniałby się obraz bardzo niepokojący, to Kongregacja może interweniować, poprzez przeprowadzenie nadzwyczajnej wizytacji apostolskiej, w duchu troski o instytut.

Ordynariusz zakonny i inni przełożeni mogą żądać przedstawienia sprawozdań finansowych od podległych im ekonomów i struktur.

\footnotetext{
${ }^{83}$ Por. Wytyczne 2014, nr 1.3.

${ }^{84}$ Por. Ekonomia w służbie charyzmatu, nr 91; Wytyczne 2014, nr 1.3.

${ }^{85}$ Por. Ekonomia $w$ służbie charyzmatu, nr 91.

${ }^{86}$ KPK 1983, kan. $592 \$ 1$. „Niniejszym podaje się do wiadomości, że w przypadku braku certyfikowanych bilansów Kongregacja ds. Instytutów Życia Konsekrowanego i Stowarzyszeń Życia apostolskiego może odmówić zatwierdzenia procedur finansowania”, Wytyczne 2014, nr 1.3.

${ }^{87}$ Por. Ekonomia w służbie charyzmatu, nr 96.
} 
Jak już wspomniano, zgodnie z kan. 637 KPK, klasztory niezależne powinny raz w roku składać sprawozdanie z zarządu ordynariuszowi miejsca; tenże ordynariusz ma prawo wglądu w sprawy gospodarcze, a więc i sprawozdania, domu zakonnego na prawie diecezjalnym.

Podstawowe są rozliczenia całoroczne. Prawo powszechne wymienia je zwłaszcza w kan. 1284 i 1287 KPK. Zarządca publicznej osoby prawnej powinien „pod koniec każdego roku sporządzić sprawozdanie z zarządu"88. Dobre sprawozdanie bazuje na prowadzonej dokumentacji, co także jest obowiązkiem administratorów, wymaganym prawem powszechnym ${ }^{89}$. Chodzi zwłaszcza o księgę przychodów i rozchodów, a także umowy i inne dokumenty i dowody, potwierdzające prawa kościelnej osoby prawnej lub instytucji do majątku.

Treść kan. 1287 również zobowiązuje do składania sprawozdań ordynariuszowi miejsca, choć kontekst tej normy wskazuje głównie na relacje wewnątrz Kościoła partykularnego, a nie na prawo zakonne. Tym niemniej warto zwrócić uwagę, że ten przepis prawny jednoznacznie odrzuca wszelkie zwyczaje przeciwne sporządzaniu sprawozdań. Zobowiązanie wiąże zarządców dóbr kościelnych, tzn. w nawiązaniu do kan. 1257: publicznych osób prawnych, a więc także struktur zakonnych.

Sprawozdawczość, jak już w tym opracowaniu wspomniano, służy również transparentności. Struktury zakonne są wówczas bardziej przejrzyste w przestrzeni ekonomicznej, co ma także znaczenie dla realizacji własnego charyzmatu życia konsekrowanego. Niewykonywanie sprawozdań przez zarządców, a z drugiej strony zaniechanie nadzoru ze strony przełożonych zakonnych może prowokować zagrożenie dla dóbr kościelnych, czy również dla wypełnienia swej charyzmatycznej roli przez instytuty.

W praktyce największa część zadania sprawozdawczości spoczywa na ekonomach zakonnych i ich współpracownikach ${ }^{90}$. Prawo

\footnotetext{
${ }^{88}$ KPK 1983, kan. $1284 \$ 2$ n. 8. Por. A. Domaszk, Dobra doczesne Kościoła, dz. cyt., s. 230-231; P. Kaleta, Kościelne prawo majątkowe, dz. cyt., s. 175-177.

${ }^{89}$ KPK 1983, kan. $1284 \$ 2$ n. 7. 9.

${ }^{90}$ Por. Ekonomia $w$ służbie charyzmatu, nr 64.
} 
powszechne stanowi: „W czasie oraz w sposób określony we własnym prawie, ekonomi i inni zarządcy mają obowiązek przedłożyć kompetentnej władzy sprawozdanie z wykonanego zarządu"91. Ekonomowie zakonni (generalny, prowincjalny, lokalny) i inni zarządcy, postępują w tym działaniu zgodnie z normami prawa własnego.

Przełożony zakonny wraz ze swoją radą analizuje złożone sprawozdania. Zależnie od sytuacji, przyjmuje je, domaga się dodatkowych wyjaśnień czy planów inwestycyjnych, podejmuje działania kontrolne lub naprawcze, stanowi decyzje władzy - na mocy swoich konstytucyjnych uprawnień, przekazuje informacje do wiadomości przełożonych zwierzchnich, ale także do zainteresowanych członków instytutu, np. w prowincji za pomocą listu okólnego itd.

Warto też zwrócić uwagę na treść drugiego paragrafu w kan. 1287, co dotyczy składania sprawozdań kierowanych do szeroko rozumianego grona wiernych, tj. poza obrębem własnych współbraci czy współsióstr. „Z dóbr ofiarowanych przez wiernych na rzecz Kościoła, zarządcy powinni przedstawiać wiernym odpowiednie sprawozdania, według norm, które winno określić prawo partykularne"92. Wydaje się, że publiczna osoba prawna, tj. najczęściej dom zakonny (lokalny), czy niekiedy prowincja powinna ogólnie informować wiernych na temat spożytkowania ofiar, jakie oni złożyli, na potrzeby tej struktury zakonnej lub na dzieła prowadzone przez nią. Chodzi nie o całościowe sprawozdanie z tego, czym zakon administruje. Lecz o te ofiary, przekazane na rzecz konkretnej publicznej osoby prawnej

\footnotetext{
${ }^{91}$ KPK 1983, kan. $636 \$ 2$. Problematykę ekonomów zakonnych, por. A. DomAszK, Funkcja ekonoma w prawie własnym Towarzystwa św. Franciszka Salezego, Seminare 27 (2010), s. 63-75; S. ReCCHI, L'ecomo negli istituti religiosi, Quaderni di Dirritto Ecclesiale 22 (2009) 2, s. 130-140; P. Kaleta, Kościelne prawo majątkowe, dz. cyt., s. 265-269; V. Mosca, Il ruolo dell'economo e i suoi diversi collaboratori nella gestione patrimoniale degli Istituti di vita consacrata e delle Società di vita apostolica, $\mathrm{w}$ : Povertà evangelica, missione e vita consacrata. I beni temporali negli Istituti di vita consacrata e nelle Società di vita apostolica, red. A. Aste, Marcianum Press, Venezia 2016, s. 65-95.

${ }^{92}$ KPK 1983, kan. 1287 \$2. Por. A. DomaszK, Dobra doczesne Kościoła, dz. cyt., s. 231-233.
} 
lub, w kontekście określonej działalności, jaką klasztor prowadzi. Mogą to być dary zbierane podczas kolekt lub też w innych formach pozyskane, np. aktem darowizny.

W kontekście Kościoła partykularnego, parafie przedstawiają tego typu rozliczenia w ostatni dzień roku lub na początku kolejnego roku kalendarzowego, co służy transparentności działalności kościelnej. Ich forma jest zwykle bardzo ogólna. Sprawozdania kierowane przez przełożonego klasztoru do wiadomości wiernych również mogą być przedstawiane na koniec roku albo na zakończenie jakiejś większej inwestycji zakonnej, np. w formie biuletynów: drukowanych lub elektronicznych. W tym miejscu należy przypomnieć, że II Synod Plenarny w Polsce także polecał, aby instytucje diecezjalne i parafie informowały wiernych o swoich dochodach oraz o sposobach ich spożytkowania, co służy kształtowaniu obrazu Kościoła wiarygodnego w sferze ekonomicznej, ale i budzeniu współodpowiedzialności za dzieła kościelne ${ }^{93}$. Podobne zalecenia zawiera instrukcja Konferencji Episkopatu Polski z 2015 r. ${ }^{94}$

Poza bezpośrednim kontekstem prawa kanonicznego występują sytuacje, kiedy kościelna osoba prawna może być zobligowana do sporządzania sprawozdań dla różnych podmiotów określonych prawem polskim. Przykładowo, przyjęcie darowizny na instytucję kościelną (zakonną) domaga się przekazania darczyńcy sprawozdania w okresie dwóch lat, na co zostały przeznaczone pieniądze, czy inne środki materialne ${ }^{95}$. Podobnie, jeśli kościelna osoba prawna uzyska środki finansowe na realizację celów gminy, miasta, czy samorządu, jest wówczas zobowiązana do szczegółowych rozliczeń z otrzymanych środków, według przepisów prawa polskiego, także lokalnego.

\footnotetext{
${ }^{93}$ Por. II Polski Synod Plenarny, Kościół wobec życia społeczno-gospodarczego, dz. cyt., nr 56.

${ }^{94}$ Por. Konferencja EPIskopatu Polski, Instrukcja w sprawie zarzadzania dobrami doczesnymi Kościoła, 25.08.2015, http://episkopat.pl/instrukcja-kep-w-sprawie-zarzadzania-dobrami-doczesnymi-kosciola/ [dostęp 16.09.2019], dalej: Instrukcja KEP/2015, nr 3.27.

${ }^{95}$ Por. Ustawa z dnia 17 maja 1989 r. o stosunku Państwa do Kościoła katolickiego w Rzeczypospolitej Polskiej, Dz. U. z 1989 r. Nr 29, poz. 154 z późn. zm., art. 55 ust. 7.
} 
Analogiczny obowiązek rozliczania i sporządzania sprawozdań dotyczy innych środków publicznych, jak otrzymanych z urzędów ministerialnych, np. remonty zabytkowych obiektów z puli Ministerstwa Kultury i Dziedzictwa Narodowego.

$\mathrm{W}$ ostatnich latach istotnie zmieniła się sytuacja prawna dotycząca ochrony danych osobowych. Dlatego sprawozdawczość, również w wydaniu podmiotów prawnych zakonnych, musi przestrzegać aktualnych wymogów w tej materii ${ }^{96}$. Oznacza to, że sprawozdania, $i$ te publicznie dostępne, i te przetwarzane na potrzeby wewnętrzne instytutu, muszą szanować zasady ochrony danych osobowych, w tym nazwisk, adresów darczyńców itd. Konferencja Episkopatu Polski w instrukcji z $2015 \mathrm{r}$ postanowiła: „Zachowując przepisy prawa polskiego dotyczące darowizn zabrania się w pozostałych przypadkach podawania do publicznej wiadomości danych osobowych darczyńców. Niedozwoloną praktyką jest odczytywanie w kościele, wywieszanie w gablotkach, zamieszczanie na stronach internetowych parafii itp. kwot, nazwisk, nazw, adresów i innych szczegółowych danych osób czy instytucji, które przekazały bądź nie ofiary lub darowizny"97.

Prawo powszechne wskazuje na obowiązek sprawozdawczości również w kontekście pobożnych dyspozycji wiernych. Ordynariusz - w tym i zakonny - jest wykonawcą wszystkich pobożnych rozporządzeń (na mocy testamentu, jak i darowizn) ${ }^{98}$. Do niego należy obowiązek czuwania, aby tzw. pobożne zapisy zostały wiernie wypełnione, a „inni wykonawcy obowiązani są, po wypełnieniu swojej funkcji,

\footnotetext{
${ }^{96}$ Por. Ustawa z dnia 10 maja 2018 r. o ochronie danych osobowych, Dz.U. z 2018 r. poz. 1000; KonferenCJa EPISKOPATU POLSKi. Dekret ogólny w sprawie ochrony osób fizycznych $w$ związku z przetwarzaniem danych osobowych $w$ Kościele katolickim, http://episkopat.pl/wp-content/uploads/2018/04/13.3.2018.PL_.Dekret-ogolny-o-ochronie-danych-osobowych.pdf. [dostęp 14.05.2018]; A. DomAszk, Ochrona danych osobowych - obowiązek duszpasterski, Prawo Kanoniczne 53 (2010), nr 3-4, s. 43-67; TEnże, Ochrona danych osobowych w Polsce a Kościót katolicki, Seminare. Poszukiwania Naukowe 40(2019)1, s. 23-36.

${ }^{97}$ Instrukcja KEP/2015, nr 3.28.

${ }^{98}$ Por. KPK 1983, kan. 1301 §1; A. Domaszk, Dobra doczesne Kościoła, dz. cyt., s. 291-294.
} 
złożyć ordynariuszowi sprawozdanie"99. W ten sposób zabezpiecza się jak najlepsze wypełnienie woli fundatora. Gdyby w ramach pobożnego zapisu zostali wyznaczeni wykonawcy, wówczas po wypełnieniu swojej funkcji mają oni kanoniczny obowiązek: złożyć sprawozdanie ordynariuszowi. Dokonanie pobożnego zapisu na rzecz domu czy prowincji zakonnej, ostatecznie domaga się podsumowania i sprawozdania z tego, jak spożytkowano zapisy testamentalne czy darowizny. Obowiązek spoczywa na wykonawcach, jeśli tacy są wyznaczeni albo na odpowiednim ekonomie domu czy prowincji.

Jedną z form pobożnych zapisów są fundacje. Treść kan. 1307 KPK czyni odesłanie do kan. 1287. Zatem administrator dóbr kościelnych - fundacyjnych - jest zobligowany obowiązkiem do składania corocznego sprawozdania właściwemu ordynariuszowi (przychody i rozchody fundacyjne) ${ }^{100}$. Gdy fundacja jest złączona ze strukturami zakonnymi i nie podlega ordynariuszowi miejsca, to adresatem obowiązku będzie ordynariusz zakonny. Ale jeśli natura instytutu nie zawiera w sobie koncepcji ordynariusza (jak instytuty laickie), a ponadto domy sui iuris oraz te na prawie diecezjalnym, to odbiorcą sprawozdania może być ordynariusz miejsca.

Obowiązek nadzorowania pobożnych zapisów wiernych wymaga sprawdzenia kompletności sprawozdań ekonomicznych. Następnie, przy okazji wizytacji kanonicznej należy sprawdzić wpisy w odpowiednich księgach, tj. również w księdze fundacyjnej. W razie potrzeby ordynariusz czy inny właściwy przełożony powinien interweniować, w sytuacji nadużyć czy niegospodarności pobożnymi zapisami $^{101}$.

Techniczne zagadnienia, co do formy sporządzania sprawozdania mogą być różne. Przede wszystkim należy stosować wewnętrzne instrukcje w instytucie. W tym także o wytworzeniu dokumentów, ich przechowywaniu i przesyłaniu oraz przechowywaniu w archiwum osoby prawnej, np. domu zakonnego. Wiodące są wskazania prawa własnego oraz decyzje (poszczególne akty administracyjne)

\footnotetext{
${ }^{99}$ KPK 1983, kan. $1301 \S 2$.

${ }^{100}$ Por. A. Domaszk, Dobra doczesne Kościoła, dz. cyt., s. 310.

${ }^{101}$ Por. tamże.
} 
kompetentnych przełożonych instytutu, zwłaszcza na poziomie zarządu centralnego i prowincjalnego.

Do obsługi administracji, co dotyczy również modułu sprawozdawczego, należy stosować nowe programy komputerowe, a to jest już praktyką w polskiej rzeczywistości. Nie należy całkowicie negować formy papierowej, która może służyć jako forma archiwizacji informacji, ewentualnie jako zabezpieczenie w razie awarii systemów informatycznych. Jednakże coraz bardziej w obsłudze domu zakonnego, prowincji i całego instytutu przydatne są programy komputerowe, które zawierają moduły ekonomiczne. Chyba, że na poziomie domu zakonnego można jeszcze stosować proste formularze kalkulacyjne, jak np. Excel.

Jedną z propozycji na polskim gruncie jest program firmy Ecclesia Software: "Zakon Finanse 2". Oprogramowanie jest przewidziane dla wielu stanowisk i służy dokumentacji finansowej i sprawozdawczości, ukierunkowane jest na podmioty zakonne (szeroko rozumiane pojęcie: instytuty życia konsekrowanego i stowarzyszenia życia apostolskiego).

„Zakon Finanse to rozbudowana książka przychodów i rozchodów. $\mathrm{Na}$ etapie wdrożenia programu wyodrębnia się placówki (jednostki autonomiczne), z których każda otrzymuje jeden egzemplarz programu. Dodatkowo wyróżnia się jedną jednostkę centralną (kuria), która ma możliwość zarówno prowadzenia autonomicznej księgowości, jak też importowania danych z innych placówek. Sama wymiana danych następuje poprzez ich przekazywanie na dyskietkach lub pocztą elektroniczną” oraz „System Zakon Finanse ma wbudowany moduł środków trwałych oraz moduł wydruków (sprawozdania okresowe, raporty kasowe, wyniki finansowe, amortyzacja środków trwałych), planowanie budżetu, a także możliwość importu i eksportu planu kont oraz danych. W przypadku, gdy któryś z domów zakonnych nie ma możliwości transmisji danych drogą elektroniczną, program na stanowisku centralnym (w kurii) umożliwia ręczne nanoszenie danych (stanów kont) dla danej jednostki. Ponadto program może być wyposażony w następujące moduły: środki trwałe i plan amortyzacji, inwentarz majątku zgromadzenia, stanowisko kasowe i profile 
płatności dla stanowiska kasowego, wydarzenia i książka kancelaryjna (zwana również dziennikiem podawczym). Dodatkowo możliwa jest integracja z nową wersją programu Zakon Ewid"102.

Na rynku istnieje wiele innych propozycji programów do obsługi ekonomiczno-księgowej. Choć zapewne trudno byłoby przełożyć specyfikę ekonomii struktur zakonnych na język ekonomiczny i programistyczny tego typu narzędzia. Jednakże na poziomie zarządzania ekonomicznego całego instytutu, a nawet prowincji, można zamówić $\mathrm{w}$ firmach informatycznych program dedykowany określonej strukturze, odpowiednio dopasowany do złożoności insty tucji i prowadzonych dzieł. Należy jednak wziąć pod uwagę, że jeśli zarząd generalny instytutu ma siedzibę w Rzymie, czy w innym miejscu na świecie, to prawdopodobnie zaistnieją liczne trudności. Przetworzenie danych i ich scalanie, gdy pochodzą z różnych programów i krajów jest trudne lub niemożliwe. Przekazanie danych ekonomicznych, w tym sprawozdań różnego rodzaju, w takiej sytuacji może wymagać przeniesienia „ręcznego" informacji z jednego na drugi program, czytelny na poziomie zarządu generalnego.

\section{Wnioski}

Aktualna myśl Magisterium Kościoła podkreśla cechę transparentności w administracji dobrami zakonnymi, czyli przejrzystości w zarządzaniu, na każdym etapie, czynności czy urzędzie. W ten sposób działania instytutów odpierają różne zarzuty osób i środowisk wrogich Kościołowi. Jednocześnie klarowność administracyjna pozwala na lepsze pozyskanie środków. Ofiarodawcy chętniej przekazują swoje dobra na cele zakonne, gdy wiedzą, na co będą przeznaczone oraz, że ich środki będą dobrze spożytkowane.

Gospodarne zarządzanie domaga się programowania, czyli planowania. Tak w krótszej perspektywie czasowej, jak np. coroczne budżety, czy jako wieloletnie plany. To z kolei domaga się inicjowania myślenia projektowego. Tak, aby działania ekonomiczne nie

\footnotetext{
${ }^{102}$ Zakon Finanse 2, http://ecclesiasoftware.com/solutions/for-convents/convent-finance/ [dostęp 17.09.2019].
} 
były jedynie jakąś spontaniczną reakcją na zaistniałe sytuacje, lecz odzwierciedlały rozumne postępowanie. A zarazem kierowanie się roztropnością i planami nie wyklucza w niczym elementu Bożej Opatrzności.

Programowanie ekonomiczne często wymaga pozyskiwania różnorakich zezwoleń, na co wskazuje prawo kanoniczne i ostatnie dokumenty Kongregacji ds. Instytutów Życia Konsekrowanego i Stowarzyszeń Życia Apostolskiego. Kompetentne osoby i organy muszą też pełnić nadzór w instytutach zakonnych nad decyzjami administracyjnymi. Nawet najlepsze plany nie staną się efektywne, gdy zabraknie stosownej kontroli. Tak tej wewnątrz instytutu, zgodnie z prawem własnym, ale również potrzebna jest, w niektórych sytuacjach, kontrola zewnętrza i tzw. audyty, zlecane podmiotom spoza instytutu. W programowaniu nie można też zapomnieć, że poszczególne struktury zakonne stanowią część większej całości, jako instytutu, ale i Kościoła lokalnego oraz powszechnego.

Programowanie i sprawozdawczość w istotny sposób łączą się i wpływają na to, że administracja dobrami zakonnymi jest transparentna, wewnątrz i na zewnątrz instytutu. Osoby konsekrowane w realizacji tak złożonych zadań powinny też korzystać z nowych narzędzi informatycznych. Współczesny obieg informacji, scalanie i przetwarzanie danych ekonomicznych nie jest już możliwe bez nowoczesnych programów komputerowych.

Myśl Kościoła przypomina, że dziedzina ekonomii jest narzędziem, zaś pieniądz ma służyć, a nie rządzić oraz że jest podporządkowany realizacji misji i charyzmatu zakonnego ${ }^{103}$. W ten sposób życie osób konsekrowanych daje świadectwo Chrystusowi i Kościołowi oraz wierze, która nie stawia dóbr materialnych na pierwszym miejscu ${ }^{104}$. Świadectwo to wskazuje, że przede wszystkim Bóg jest prawdziwym bogactwem życia ludzkiego, by na koniec przywołać myśl Jana

\footnotetext{
${ }^{103}$ Por. Ekonomia w służbie charyzmatu, nr 14.

${ }^{104}$ Por. JAN PAweŁ II, Posynodalna adhortacja apostolska o życiu konsekrowanym i jego misji w Kościele $i$ w świecie „Vita consecrata”, 25.03.1996, Apostolicum, Ząbki 1996, nr 89-90.
} 
Pawła II: „Dlatego właśnie ewangeliczne ubóstwo przeciwstawia się z całą mocą bałwochwalczemu kultowi mamony i staje się proroczym wezwaniem skierowanym do społeczeństwa, które żyjąc w wielu częściach świata w dobrobycie, jest wystawione na niebezpieczeństwo utraty poczucia umiaru i świadomości istotnej wartości rzeczy”105.

\section{Transparency, the programmability and the economic reporting religious institutes}

Canon law regulates issues, including the ones regarding poverty in religious institutes. As initially, also today, people and communities of consecrated life embrace the "poor lifestyle". To follow this lifestyle, in today's administration of material goods, among others, words such as transparency, programmability, reporting are becoming the necessary benchmarks. The study discusses these three areas based on canon law and the document Economia a servizio del carisma e della missione.

The current thought of the Magisterium of the Catholic Church emphasizes the feature of transparency in the administration of religious goods, i.e., transparency in management at every stage, every activity or office. In this way, the activities of the institutes refute various accusations of persons and environments hostile to the Church. At the same time, administrative clarity makes more effective fundraising possible. Donors are more willing to donate their goods for religious purposes when they know these purposes and are sure that their funds will be well spent.

Economical management requires programming or planning, both in the shorter time perspective (budget) and from the perspective of long-term plans. This, in turn, requires initiating design thinking. So that economic activities are not just some spontaneous reaction to the situations but reflect intelligent behaviour. At the same time, following prudence and plans does not exclude an element of God's providence.

Economic programming often requires obtaining various permits, as indicated by canon law and recent documents of the Congregation for Institutes of Consecrated Life and Societies of Apostolic Life. Competent persons and bodies must also supervise administrative decisions at religious institutes. Even the best plans will not become effective if one does not

\footnotetext{
105 Tamże, nr 90.
} 
have adequate control. In programming, one cannot forget that individual religious structures are part of a larger whole, as an institute, but also a local and universal Church.

Programming and reporting significantly combine and make the administration of religious goods transparent, inside and outside the institute. Consecrated persons in carrying out such complex tasks should also use new IT tools. Modern circulation of information, merging, and processing of economic data is no longer possible without modern computer software.

The Church's thought reminds us that the field of economics is a tool and that money is to serve, not rule, and it is subordinated to the religious mission and charism. In this way, the lives of consecrated people bear witness to Christ and the Church and to the faith that does not put material goods first. This witness indicates that, above all, God is the real wealth of human life.

SŁOWA KLUCZOWE: prawo kanoniczne; ekonomia; administracja; dobra zakonne; charyzmat zakonny

KEYwORDs: the canon law; the economy; the administration; religious goods; religious charisma

\section{Nota O AUTORZE}

Ks. DR hAB. Arkadiusz Domaszk SDB Prof. UCZ. - absolwent Uniwersytetu Kardynała Stefana Wyszyńskiego w Warszawie, profesor uczelni na Wydziale Prawa Kanonicznego UKSW w Warszawie, wykładowca w Wyższym Seminarium Duchownym SDB w Krakowie. Zainteresowania naukowe: dobra doczesne Kościoła, prawo o posłudze nauczania, mass media a prawo kanoniczne, prawo zakonne, prawo wyznaniowe. 